\title{
Človekovo dostojanstvo kot ustavnopravni temelj načela zaslišanja stranke $v$ upravnem postopku
}

UDK: $342.34: 35.077 .3$

\author{
Iztok Rakar \\ Univerza v Ljubljani, Fakulteta za upravo \\ iztok.rakar @fu.uni-lj.si
}

\section{IZVLEČEK}

Odločanje v upravnem postopku sicer pomeni oblastno obliko delovanja, vendar to ne pomeni, da mora biti tako delovanje tudi avtoritarno. Upravni postopek mora biti namreč v sodobni demokratični državi oblikovan in izvajan tako, da se ne kršijo temeljne ustavne vrednote, pri čemer je ena od najpomembnejših človekovo dostojanstvo. Po našem mnenju je človekovo dostojanstvo v upravnem postopku primarno zavarovano $z$ možnostjo posameznika, da sodeluje v postopku odločanja o njegovih pravicah, dolžnostih ali pravnih koristih. Dana mu mora biti možnost, da se udeležuje postopka ugotavljanja dejstev, pomembnih za odločitev, da se izjavi o vseh dejstvih in okoliščinah, pomembnih za odločitev in izpodbija ugotovitve in navedbe organa in nasprotnih strank ter drugih udeležencev postopka (načelo zaslišanja stranke). Na ta način se posameznik v postopku obravnava kot subjekt in ne kot objekt, s čimer je na primarni ravni zavarovano njegovo dostojanstvo. Glede na to menimo, da je varstvo človekovega dostojanstva eden od glavnih ustavnopravnih temeljev načela zaslišanja stranke $v$ upravnem postopku, zato se je treba $v$ primeru kršitve le-tega sklicevati tudi na kršitev človekove pravice do dostojanstva. V prispevku je poleg primerjalnih ustavnopravnih podlag načela zaslišanja stranke $v$ upravnem postopku podrobneje prikazana zakonska konkretizacija tega ustavnega temelja v slovenskem in nemškem pravu ter v pravu EU.

Ključne besede: pravo, ustavno pravo, upravni postopek, stranke

\section{Uvod}

$\checkmark$ upravnem postopku gre za reševanje nasprotja med posamičnim in javnim interesom, ki ga mora organ s svojo odločitvijo razrešiti. Čeprav gre v tem primeru za obliko oblastnega delovanja, to ne pomeni, da mora biti tako delovanje tudi avtoritarno. Upravni postopek mora biti $\vee$ sodobni demokratični državi namreč oblikovan in izvajan tako, da se ne kršijo temeljne ustavne vrednote. Ena izmed 
Iztok Rakar

Človekovo dostojanstvo kot ustavnopravni temelj načela

zaslišanja stranke $v$ upravnem postopku

teh je nedvomno človekovo dostojanstvo. Izhodiščna teza prispevka je, da varstvo človekovega dostojanstva predstavlja enega od glavnih ustavnopravnih temeljev načela zaslišanja stranke $v$ upravnem postopku.

\section{Upravni postopek kot klasičen primer oblastne- ga razmerja med državo in posameznikom}

$\checkmark$ upravnem postopku se odloča o upravnih zadevah, ki jih je s formalnega zornega kota mogoče opredeliti kot odločanje o pravici, obveznosti ali pravni koristi fizične ali pravne osebe oziroma druge stranke na področju upravnega prava. Z materialnega zornega kota pa je opredelitev nekoliko težja, saj gre za vprašanje vsebine realnega družbenega razmerja, ki se $\vee$ abstraktni upravni normi opredeli kot upravna zadeva. S tega zornega kota se upravna zadeva kaže kot obstoječe ali predvidljivo nasprotje med posamičnim in javnim interesom, ki ga mora organ s svojo odločitvijo razrešiti. ${ }^{1}$ Odločanje $v$ upravnem postopku se praviloma konča $z$ izdajo odločbe kot enostranskega oblastnega pravnega akta, ki ga organ izda $v$ okviru izvajanja oblastne funkcije brez pogajanja s stranko kot nadrejeni subjekt. ${ }^{2}$ Gre torej za klasičen primer oblastnega razmerja med posameznikom ${ }^{\mathbf{3}}$ in državo, ki ga je $v$ sodobnih demokratičnih državah treba postaviti $v$ ustavnopravni okvir. To predvsem pomeni, da tako razmerje ni avtoritarno $v$ smislu samovolje in ignorantskega odnosa države do posameznika. Končno odločitev res sprejme državni organ samostojno in $v$ tej fazi ni mogoče govoriti o enakopravnem položaju obeh strani, vendar je to zgolj ena od faz pravno urejenega postopka ene od oblik delovanja države. Upravni postopek kot celota mora biti urejen tako, da se zagotavlja spoštovanje temeljnih ustavnih vrednot, ki se nanašajo na razmerje med državo in posameznikom - ena izmed njih je nedvomno človekovo dostojanstvo. ${ }^{4}$

1 Trpin v Jerovšek in Trpin, 2004, str. 39.

2 Kovač v Jerovšek in Trpin, 2004, str. 571.

3 Dostojanstvo se veže na človeka (glej Jarass v Jarass in Pieroth, 2004, str. 44-45, r. št. 5-6 in Šturm v Šturm, 2002, str. 364, r. št. 7-8). Človek je s stališča prava lahko nosilec pravic in obveznosti, torej pravni subjekt (fizična oseba). Sposobnost biti stranka $v$ upravnem postopku se veže predvsem na pravno sposobnost, lastnost stranke v konkretnem upravnem postopku pa ima subjekt, ki je lahko nosilec pravic in obveznosti, o katerih se odloča v upravnem postopku (Mužina $\vee$ Jerovšek in Trpin, 2004, str. 180-184). $\vee$ tem prispevku bomo zaradi osredotočenosti na človekovo dostojanstvo za človeka, ki ima lastnost stranke v upravnem postopku ali enake pravice kot le-ta, uporabljali izraz posameznik, razen kadar bo govora o konkretni zakonski ureditvi procesnih institutov (primerjaj Pavčnik, 2001, str. 99 sl. in Toporišič et al., 2003, str. 1172).

4 Več o funkcijah procesnega prava in pomenu procesnih pravic glej v Allan (1998), Ponce, 2004, str. 2-3, Nehl, 1999, str. 20-26, Kerševan, 2004, str. 2-3 in Kanska, 2004, str. 323. 


\section{Ustavnopravni temelji upravnega postopka}

\subsection{Uvod}

Upravni organi so pri svojem delovanju vezani na ustavo in zakon. Ustavne vrednote, ki so $v$ ustavi med drugim izražene tudi v obliki ustavnih načel, so v zakonodaji, ki ureja položaj in delovanje uprave, praviloma izrecno povzete (zakonska načela) in nadalje konkretizirane $v$ obliki pravnih pravil in sankcij (pravnih sredstev), ki omogočajo njihovo uveljavitev $v$ praksi. ${ }^{\mathbf{5}}$ Ker se $v$ upravnem postopku odloča o pravici, obveznosti ali pravni koristi posameznika, se kot eno od osnovnih vprašanj pravne ureditve le-tega kaže $v$ njegovi pravici, da pri tem sodeluje, torej da se udeležuje postopka ugotavljanja dejstev, pomembnih za odločitev, da se izjavi o vseh dejstvih in okoliščinah, pomembnih za odločitev in izpodbija ugotovitve in navedbe organa in nasprotnih strank ter drugih udeležencev postopka (t.i. načelo zaslišanja stranke / audiatur et altera pars). ${ }^{\mathbf{6}} \mathrm{Na}$ ta način se posamezniku omogoči, da zavaruje svoje pravice, pojasni dejstva, na katerih temelji odločanje o zadevi, s čimer lahko vpliva na potek postopka in na sprejeto odločitev, ki naj bi bila zaradi tega materialnopravno pravilna in ne popolno presenečenje. ${ }^{7}$ Bistvo tega prispevka je ugotoviti, kateri so glavni ustavnopravni temelji načela zaslišanja stranke $\vee$ upravnem postopku. Naša teza je, da je treba tudi $v$ slovenskem ustavnopravnem sistemu kot temeljno ustavno podlago načela zaslišanja stranke šteti varstvo človekovega dostojanstva, s čimer razumemo zahtevo, da se posameznik ne obravnava kot objekt, ampak kot subjekt. ${ }^{\mathbf{V}} \mathrm{V}$ slednjem primeru se med državo in posameznikom vzpostavi posebno razmerje, ki ga Kerševan (2005, str. 8) imenuje "notranja kontradiktornost " in katerega bistvo je $v$ tem, da kljub nadrejenosti organa omogoča soočenje uradne osebe $z$ drugačnim videnjem posameznika o relevantnih vidikih dejanskega in pravnega stanja. ${ }^{\boldsymbol{9}}$

5 Podrobneje o tem v Kerševan, 2001.

6 Jerovšek v Jerovšek in Trpin, 2004, str. 86.

7 Allan, 1998, str. 515 in Bonk in Kallerhoff v Stelkens et al., 2001, str. 692-693, r. št. 16.

8 Gre za t.i. formulo objekta (Objektformel), ki jo je zaradi težavnosti pozitivne definicije človekovega dostojanstva razvila nemška ustavnopravna doktrina in povzela ustavnosodna praksa in ki izvira iz etičnega nauka Immanuela Kanta (Grundlegung der Metaphysik der Sitten). Primerjaj z odločbo Ustavnega sodišča Republike Slovenije št. Up-39/95 z dne 16. 1. 1997, Kerševan, 2004, str. 2, Tribe v Allan, 1998, str. 498 in Kanska, 2004, str. 302.

9 Seveda pa iz procesnih pravic, ki izhajajo iz načela zaslišanja stranke, ne izhaja dolžnost, da bi upravni organ odločitev sprejel v soglasju s stranko - kot že povedano upravni organ namreč odloči samostojno (glej npr. 120. člen Ustave Republike Slovenije, 2. člen zakona o državni upravi in 12. člen zakona o splošnem upravnem postopku) in enostransko ter je $v$ tem oziru stranki nadrejen. Razlog za slednje je $v$ varstvu javne koristi (Kovač v Jerovšek in Trpin, 2004, str. 571, primerjaj Bonk in Schmitz v Stelkens et al., 2001, str. 446, r. št. 5 in Kanska, 2004, str. 232). 
Iztok Rakar

Človekovo dostojanstvo kot ustavnopravni temelj načela

zaslišanja stranke $v$ upravnem postopku

\subsection{Ustavnopravni temelji načela zaslišanja stranke v upravnem postopku}

Slovenska teorija in ustavnosodna praksa kot glavna ustavnopravna temelja načela zaslišanja stranke navajata načelo demokratičnosti in načelo enakega varstva pravic, nemška teorija iz načela pravne države izpeljano zahtevo po poštenem postopku in varstvo človekovega dostojanstva, angleška ${ }^{\mathbf{1 0}}$ teorija to načelo (oziroma pravico) ${ }^{\mathbf{1 1}}$ umešča $\vee$ okvir načel pravičnosti (natural justice), ameriška teorija pa $\vee$ okvir poštenega postopka (procedural due process). ${ }^{\mathbf{1 2}}$ Vsebina le-teh se med seboj tesno prepleta in povezuje.

\subsubsection{Načelo demokratičnosti}

$\checkmark$ skladu z načelom demokratičnosti mora volja ljudstva vsebinsko določati in nadzorovati katerokoli izvrševanje državne oblasti. ${ }^{13}$ Gre torej za to, da ljudstvo kot nosilec oblasti z le-to konkretno razpolaga in jo izvršuje oziroma da učinkovito vpliva na njeno izvrševanje. Sodelovanje posameznika $v$ upravnem postopku torej pomeni možnost vpliva na potek postopka in njegov rezultat (vsebino odločitve), torej izvajanje oblasti v konkretnem primeru, hkrati pa tudi obliko nadzora nad delovanjem upravnega organa. Ker se posameznik (tudi) na ta način seznani z razlogi, na katerih bo temeljila odločitev, ima tudi legitimacijsko funkcijo, saj pripomore k večji sprejemljivosti odločitve. ${ }^{14}$

\subsubsection{Načelo pravne države}

Načelo pravne države je eno od splošnih temeljnih ustavnih načel, iz katerega so izvedena druga splošna ustavna načela, in sicer ne glede na to, ali so $v$

$10 \mathrm{~V}$ prispevku bomo uporabljali izraz "angleško" v primerih, ko gre za teorijo, ki temelji na praksi angleških sodišč, ki so izoblikovala načela občega prava (common law). Podrobneje o pravnem in sodnem sistemu Združenega kraljestva Velike Britanije in Severne Irske v Bogdanor, 2003, str. $585 \mathrm{sl}$.

11 Terminologija ni dosledna, glej npr. Wade in Forsyth, 2004, str. 476.

12 Jerovšek v Jerovšek in Trpin, 2004, str. 86, Jambrek v šturm, 2002, str. 48, r. št. 19, Testen, ibid., str. 238-239, r. št. 1, odločba Ustavnega sodišča Republike Slovenije, št. Up-17/95 z dne 4. 7. 1996, Stelkens v Stelkens et al., 2001, str. 135, r. št. 30, Maurer, 2004, str. 485, r. št. 9 , Wade in Forsyth, 2004, str. 476 sl., Craig in Tomkins, 2006, str. 44, Sullivan in Gunther, 2004, str. 629 sl. in Kanska, 2004, str. 301.

13 Jerovšek v Jerovšek in Trpin, 2004, str. 9; enako Jambrek v Šturm, 2002, str. 48, r. št. 19. $14 \mathrm{~V}$ skladu s teorijo demokratične legitimacije gre $v$ tem delu za stvarno-vsebinsko obliko demokratične legitimacije, ki je tesno povezana z organizacijsko-personalno (o tem Jambrek v Šturm, 2002, str. 48-50, primerjaj Allan, 1998, str. 498-499). 


\section{Iztok Rakar \\ Človekovo dostojanstvo kot ustavnopravni temelj načela zaslišanja stranke $v$ upravnem postopku}

ustavah izrecno napisana ali ne. Eno izmed teh načel je tudi načelo poštenega (fair) obravnavanja v postopkih pred sodišči in drugimi državnimi organi. ${ }^{\mathbf{1 5}}$

Načelo poštenega obravnavanja je po Šturmovem mnenju (2002, str. 55) v slovenski ustavi izrecno urejeno s posebnimi ustavnimi določbami, ki se nanašajo na procesna in vsebinska varovala v kazenskem, upravnem in drugih postopkih pred državnimi organi oziroma drugimi nosilci javnih pooblastil. ${ }^{\mathbf{1 6}} \mathrm{V}$ ta okvir je nedvomno mogoče umestiti tudi načelo zaslišanja stranke $v$ upravnem postopku.

$\checkmark$ angleškem pravnem prostoru je načelo zaslišanja (hear the other side) eno od najbolj pomembnih načel pravičnosti (natural justice) kot dela načela ultra vires, saj se nanaša na skoraj vsako vprašanje poštenega postopka (fair procedure). ${ }^{17} \mathrm{~V}$ svoji širini zajema tudi načelo nepristranskosti (rule against bias I nemo iudex in re sua), saj mora biti pošteno zaslišanje tako, da je nepristransko. Gre za stoletja staro načelo, v skladu s katerim oblastni organi ne morejo veljavno izvajati svojih oblastnih pooblastil, če prizadetim subjektom ne dajo možnosti, da povedo svoje mnenje. ${ }^{\mathbf{1 8}}$ Oblast se mora izvajati premišljeno in pošteno (considerately and fair). Na podlagi pravice do zaslišanja so angleška sodišča $^{19}$ izoblikovala sistem poštenega upravnega postopanja, ki ga je mogoče primerjati z ameriškim due process of law. ${ }^{\mathbf{2 0}}$

15 Šturm v Šturm, 2002, str. 53-55. Primerjaj s 6. členom Evropske konvencije o človekovih pravicah in sodno prakso Evropskega sodišča za človekove pravice (European Court of Human Rights: ECHR).

16 Pri tem navaja člene 17 do 31 Ustave Republike Slovenije. Menimo, da bi bilo treba v tem okviru omeniti tudi 34. člen, ki določa, da ima vsakdo pravico do osebnega dostojanstva in varnosti, čeprav podobno določa tudi 21. člen, ki se nanaša na varstvo človekove osebnosti in dostojanstva ("Zagotovljeno je spoštovanje človekove osebnosti in njegovega dostojanstva $v$ kazenskem in $v$ vseh drugih pravnih postopkih /.../.». Zupančič sicer meni, da naslov 21. člena zavaja, kajti na tem mestu naj ne bi šlo za splošno in pozitivno varovanje človekove osebnosti in dostojanstva, ampak zgolj za varstvo le-tega $v$ okviru pravnih postopkov aretacij, v priporu in pri prestajanju kazni $v$ zaporu (Zupančič v šturm, 2002, str. 236-237, r. št. 2). Menimo, da vsebina tega člena dopušča širšo razlago, saj izrecno govori tudi o drugih postopkih.

17 O razmerju med izrazoma natural justice in fairness glej Craig, 2003, str. 415-418 in Wade in Forsyth, 2004, str. 440 in 492-494.

18 Wade in Forsyth, 2004, str. 439-442 in 476; Craig, 2003, str. 407. Prvi primeri datirajo v drugo polovico 19. stoletja, "razcvet" pa je to načelo doživelo po primeru Ridge v. Baldwin leta 1963. Za razvoj širine uporabe tega načela $v$ različnih vrstah postopkov oblastnih organov glej Wade in Forsyth, 2004, str. 482-496.

$19 \mathrm{~K}$ uveljavitvi načela pravičnosti so prispevala tudi specializirana sodišča (tribunal) in zakonodaja na področju t.i. poizvedovanj (statutory inquiry) kot upravna tehnika, ki ima isti namen kot pravna načela pravičnosti - zagotoviti pošteno in razumno izvajanje pooblastil uprave (Wade in Forsyth, 2004, str. 476, Bignami, 2005, str. 24 in Craig, 2003, str. 408).

20 Wade in Forsyth, 2004, str. 476 in 492; primerjaj Braibant, 1992 (2002), str. 195. 
Iztok Rakar

\section{Človekovo dostojanstvo kot ustavnopravni temelj načela} zaslišanja stranke $v$ upravnem postopku

$\checkmark$ nemški teoriji se pravica do poštenega postopka (faires Verfahren) povezuje z načelom pravne države (Rechtsstaat) šele $v$ novejšem času. ${ }^{\mathbf{2 1}}$ Bistvena vsebina te pravice je, da se posamezniku mora dati možnost, da se pred odločitvijo o posegu $\vee$ njegove pravice izjavi o dejstvih in okoliščinah, ki so pomembne za odločitev, da bi na ta način kot subjekt lahko vplival na postopek in njegov rezultat. To načelo ne velja samo $v$ civilnih, kazenskih in disciplinskih postopkih, ampak tudi $v$ upravnih postopkih. ${ }^{22}$

\subsubsection{Načelo socialne države}

Načelo zaslišanja stranke nemška teorija povezuje tudi z načelom socialne države. Načelo socialne države je namreč eden od ustavnopravnih temeljev dolžnosti upravnega organa, da skrbi za pravice strank (Betreuungspflicht / dilligent administration), le-ta pa se nanaša na vse procesne pravice, torej tudi na pravico do zaslišanja stranke. ${ }^{\mathbf{2 3}}$

\subsubsection{Načelo enakosti}

Zaslišanje stranke $v$ upravnem postopku temelji tudi na zahtevi po enakosti pred zakonom oziroma enakem varstvu pravic kot posebnem izrazu te zahteve. Za ta prispevek je pomemben predvsem tisti vidik tega načela, v skladu s katerim mora biti v postopkih pred sodišči in pred drugimi državnimi organi, organi lokalnih skupnosti in nosilci javnih pooblastil zagotovljena enakopravnost med strankami, ki so udeležene v postopku (t.i. enakost orožij). Gre za eno od temeljnih določil, ki zagotavlja nepristranskost in s tem tudi poštenost postopka ter ustreznost odločanja. ${ }^{\mathbf{2 4}}$

21 Bistvena vsebina načela pravne države je bila namreč tradicionalno zaobsežena $v$ načelu zakonitosti delovanja izvršilne oblasti (Gesetzmäßigkeit) (Jarass v Jarass in Pieroth, 2004, str. 540 , r. št. 31).

22 Ustava Zvezne Republike Nemčije (Grundgesetz: GG) govori o pravici do zaslišanja neposredno samo v zvezi s sodnimi postopki (rechtliches Gehör - 1. odst. 103. člena GG). Tudi teorija in ustavnosodna praksa to določbo GG razlagata tako, da ne velja niti neposredno niti analogno za upravne organe (glej BVerfG 101, 397/405, Jarass v Jarass in Pieroth, 2004, str. 540, r. št. 31a in Pieroth, ibid., str. 1121, r. št. 5). Ker pa je ista vsebina zaobsežena v zahtevi po poštenem postopku, ki je izvedena iz načela pravne države, je določba 1. odst. 103. člena GG zgolj lex specialis.

23 P. Stelkens in Kallerhoff v Stelkens et al., 2001, str. 626-627; primerjaj Zalar, 2001, str. 9. Povezavo načela varstva pravic strank z načelom zaslišanja stranke navaja tudi slovenska upravnopravna doktrina, čeprav ju ne povezuje z ustavnim načelom socialne države (glej Jerovšek v Jerovšek in Trpin, 2004, str. 76-77) in sodna praksa Sodišča Evropskih skupnosti (glej Kanska, 2004, str. 305 in 322; primerjaj Nehl, 1999, str. 101 sl.).

24 Testen v Šturm, 2002, str. 238-239, r. št. 1 in Jerovšek v Jerovšek in Trpin, 2004, str. 86. Zahteva po enakosti orožij se nanaša predvsem na razmerja med strankami z nasprotnimi interesi, pri čemer pa ni mogoče izključiti tudi primera, ko je neenakost orožij podana $v$ razmerju med organom in stranko. V zadevah Up-278/97 z dne 9. 10. 1997 in U-I-23/93 z dne 20. 3. 1997, ki jih je obravnavalo Ustavno sodišče Republike Slovenije, je npr. šlo za primer, ko je 


\section{Iztok Rakar \\ Človekovo dostojanstvo kot ustavnopravni temelj načela zaslišanja stranke $v$ upravnem postopku}

\subsection{Posebej o varstvu človekovega dostojanstva}

Čeprav človekovo dostojanstvo predstavlja eno od temeljnih vrednot pravnega reda, je njegova pravna definicija težavna. Pojem človekovega dostojanstva je namreč odraz filozofske ideje o človeku, ki ima ne glede na izvor, spol, vero, narodnost ali katerokoli drugo razlikovalno okoliščino zgolj na podlagi obstoja neko lastno vrednost, ki je ne more izgubiti in mu je nihče ne more odvzeti. Zaradi težavnosti pozitivne opredelitve se človekovo dostojanstvo praviloma definira negativno, torej z opredelitvijo njegovih kršitev. Izhajajoč iz tega in iz narave oblastnega odločanja $v$ upravnem postopku je mogoče človekovo dostojanstvo opredeliti kot prepoved, da bi se človek $v$ postopkih pred državnimi organi obravnaval kot objekt.

Človekovo dostojanstvo je vrednota, ki je ne varujejo samo ustave sodobnih demokratičnih držav ${ }^{\mathbf{2 5}}$, ampak tudi mednarodnopravni dokumenti in temeljni akti naddržavnih tvorb kot je npr. Evropska unija. Sklicevanje na človekovo dostojanstvo se najprej pojavi v preambuli Ustanovne listine Združenih naro$\operatorname{dov}^{\mathbf{2 6}}$, nato pa še $\vee$ Splošni deklaraciji človekovih pravic ${ }^{\mathbf{2 7}}, \vee$ Mednarodnem paktu o državljanskih in političnih pravicah ${ }^{\mathbf{2 8}}$ in končno $v$ Pogodbi o Ustavi za Evropo $^{29}$.

Glede na povedano menimo, da je osnovni ustavnopravni temelj načela zaslišanja stranke $\mathrm{v}$ upravnem postopku dejansko zahteva po varstvu človekovega dostojanstva, pri čemer mislimo na to, da se posamezniku mora dati možnost sodelovanja $v$ postopku odločanja o njegovih pravicah, dolžnostih ali pravnih koristih. Na ta način se posameznik iz objekta postopka "prelevi« v

zakon stranki onemogočal dokazovanje nekega dejstva, državnemu organu pa je bilo omogočeno pridobivanje dokazov, s katerimi je lahko $v$ bistvu dokazoval nasprotno dejstvo. Ustavno sodišče je odločilo, da je taka razlaga zakona $v$ nasprotju z načelom enakega varstva pravic. Breznik podobno navaja, da je načelo zaslišanja stranke kršeno, če upravni organ uporabi dokaze, ki so zaupne narave in stranki niso dostopni (Breznik v Breznik et al., 2004, str. 96, glej 5. odst. 82. člena in 158. člen ZUP; primerjaj Kanska, 2004, str. 318 in Bignami, 2005, str. 24 in 26).

25 Čeprav človekovo dostojanstvo $v$ nekaterih aktih ni izrecno omenjeno, je treba šteti, da gre $v$ teh primerih za eno od nepisanih ustavnih načel sodobnih demokratičnih držav.

26 "We the peoples of the united nations determined/.../ to reaffirm faith in fundamental human rights, in the dignity and worth of the human person«.

27 "Vsi ljudje se rodijo svobodni in imajo enako dostojanstvo in enake pravice» (1. člen).

28 "Države pogodbenice tega Pakta so se v prepričanju, da pomeni po načelih, razglašenih v Ustanovni listini Združenih narodov, priznanje dostojanstva, ki je prirojeno vsem članom človeške družine, ter priznanje njihovih enakih in neodtujljivih pravic, temelj svobode, pravičnosti in miru na svetu, v spoznanju, da izvirajo te pravice iz dostojanstva, ki je prirojeno človekovi osebnosti, /.../“ (preambula).

29 "Unija temelji na vrednotah spoštovanja človekovega dostojanstva /.../« (člen I-2) (Vrednote Unije), "Unija /.../ temelji na nedeljivih in univerzalnih vrednotah človekovega dostojanstva/.../" (II. Del, Listina Unije o temeljnih pravicah, preambula) in "človekovo dostojanstvo je nedotakljivo. Treba ga je spoštovati in varovati." (člen II-61). 


\section{Iztok Rakar \\ Človekovo dostojanstvo kot ustavnopravni temelj načela zaslišanja stranke v upravnem postopku}

subjekt postopka, kar pomeni, da se ne obravnava kot breme ali strošek. Nemožnost sodelovanja $\vee$ postopku torej pomeni primarno obliko kršitve človekovega dostojanstva. Vse ostale oblike kršitev (npr. žalitve organa v medsebojni komunikaciji oziroma pri vodenju upravnega postopka) so torej časovno gledano šele sekundarne.

Primerjalnopravno gledano je povezava načela zaslišanja stranke $v$ upravnem postopku z varstvom človekovega dostojanstva izrazito poudarjena $v$ nemški ustavnopravni doktrini in praksi. Ustava Zvezne Republike Nemčije (Grundgesetz: GG) človekovo dostojanstvo postavlja dobesedno na prvo mesto, saj je njegovo varstvo zagotovljeno $\vee$ 1. odst. 1 . člena $\mathrm{GG}^{\mathbf{3 0}} \mathrm{Iz}$ tega osnovnega izhodišča sledi povezava $z$ drugimi ustavnimi načeli, zlasti načelom pravne države in iz njega izvedenim načelom poštenega postopka, načelom enakosti in načelom socialne države.

$\mathrm{Ne}$ glede na to, da umestitev varstva človekovega dostojanstva na prvo mesto $\vee$ GG izhaja iz nemške izkušnje z nacionalsocializmom, menimo, da je tudi $\vee$ slovenski ustavnopravni ureditvi človekovo dostojanstvo treba šteti za osnovni temelj zahteve po zaslišanju stranke. Glavni argument za to stališče je $\checkmark$ tem, da je smisel temeljnih človekovih pravic kot celote varstvo človekovega dostojanstva nasproti državi. Vse $\vee$ ustavi navedene procesne garancije, ki $v$ obliki človekovih pravic in temeljnih ustavnih načel zagotavljajo pošten postopek, torej $v$ osnovi izvirajo iz varovanja človekovega dostojanstva $v$ razmerju do države. Človekovo dostojanstvo je namreč izvor in skupno vrednostno izhodišče temeljnih človekovih pravic. ${ }^{\mathbf{3 1}}$ Gre za osrednje vrednostno merilo, ki je pravno operacionalizirano prek ustavnih načel in temeljnih človekovih pravic. ${ }^{\mathbf{3 2}}$

Ta teza ne bi vzdržala, če človekove pravice v slovenski ustavni ureditvi ne bi imele osrednjega pomena. Vendar temu ni tako - pregled ustavnih dokumentov namreč pokaže, da so bile človekove pravice in temeljne svoboščine eno od osrednjih izhodišč, ciljev in namenov, zaradi katerih je bila sprejeta nova slovenska ustava. Varstvo in zagotavljanje le-teh je namreč vsebovano $v$ preambuli ustave, ustava pa izhaja iz Temeljne ustavne listine o samostojnosti in neodvisnosti Republike Slovenije (TUL), ki v svoji preambuli med drugim ugotavlja, da (so) se $\vee$ SFRJ hudo kršijo(le) človekove pravice, $v$ normativnem delu pa določa, da Republika Slovenija zagotavlja njihovo varstvo. Glede na navedeno je tudi $v$ slovenskem ustavnopravnem sistemu kot enega od osrednjih name-

30 Sprememba ustave na tem področju ni dopustna (3. odst. 79. člena GG). Klasično stališče nemške doktrine, po katerem človekovo dostojanstvo ne more biti predmet tehtanja z drugimi ustavnimi vrednotami, $v$ zadnjem času $v$ zvezi z uporabo genske tehnologije in ravnanjem $z$ vojnimi ujetniki postaja predmet kritike (glej Böckenförde, 2004).

31 To ni le mnenje slovenske teorije in ustavnosodne prakse, ampak tudi splošno javno mnenje (glej Igličar v Pavčnik et al., 1997, str. 126-127).

32 Pavčnik v Pavčnik et al., 1997, str. 97 in 99, Igličar, ibid., 1997, str. 126-127. 


\section{Človekovo dostojanstvo Rakar zaslišanja stranke $v$ upravnem postopku}

nov varstva temeljnih človekovih pravic mogoče šteti varstvo človekovega dostojanstva. ${ }^{\mathbf{3 3}}$ Varovanja človekovega dostojanstva pa si v upravnem postopku ni mogoče zamišljati brez pravice posameznika, da sodeluje $\vee$ postopku odločanja o njegovih pravicah, obveznostih in pravnih koristih na ta način, da ima pravico, da se udeležuje postopka ugotavljanja dejstev, pomembnih za odločitev, izjavi o vseh dejstvih in okoliščinah, pomembnih za odločitev in izpodbija ugotovitve in navedbe organa in nasprotnih strank ter drugih udeležencev postopka. Načelo zaslišanja stranke $v$ upravnem postopku ima zato primarni temelj $\vee$ varstvu človekovega dostojanstva, kar je tudi osrednji namen varstva človekovih pravic.

$\checkmark$ skladu $s$ tem se je po našem mnenju $v$ primeru kršitve tega načela $v$ postopkih pravnega varstva treba sklicevati tudi na kršitev človekove pravice do dostojanstva. Kot že povedano pri tem ne mislimo na tisti vidik kršitve človekovega dostojanstva, ki se nanaša npr. na žalitve organa ${ }^{\mathbf{3 4}}$, ampak kakršnekoli procesne kršitve (predvsem opustitve), ki posamezniku onemogočajo ali ga ovirajo pri izvrševanju njegovih procesnih pravic, ki pomenijo konkretizacijo ustavnih izhodišč in zakonskega načela zaslišanja stranke $v$ upravnem postopku. Te kršitve posameznika postavljajo $v$ vlogo objekta postopka in s tem kršijo njegovo dostojanstvo kot eno od temeljnih vrednot slovenskega ustavnopravnega sistema. Ena od ključnih vlog upravnega procesnega prava in procesnih pravic strank je namreč varstvo posameznika nasproti državi. ${ }^{\mathbf{3 5}}$

33 Slovenska ustava v preambuli in v splošni določbah sicer ne govori izrecno o človekovem dostojanstvu, vendar teoretiki menijo, da je mogoče to vrednostno izhodišče izpeljati iz načela demokratične države (glej Igličar v Pavčnik et al., 1997, str. 126 in Šturm v Šturm, 2002, str. 362, r. št. 1-2). Poleg tega je človekovo dostojanstvo izrecno varovano kot človekova pravica (21. člen - varstvo človekove osebnosti in dostojanstva in 34. člen - pravica do osebnega dostojanstva in varnosti). Da je človekovo dostojanstvo od najpomembnejših ustavnih vrednot, je razvidno tudi iz tega, da Ustava ne dopušča nobenega začasnega razveljavljanja ali omejevanja te človekove pravice (2. odst. 16. člena Ustave sicer govori le o 21. členu Ustave, ne pa tudi o 34. členu, vendar glede na $v$ opombi 16 povedano menimo, da ni zaobseženo zgolj varovanje človekovega dostojanstva $v$ kazenskih zadevah). Ta človekova pravica je torej na samem vrhu brezpogojno ustavno varovanih vrednot (Šturm v Šturm, 2002, str. 206, r. št. 3).

34 Te vrste kršitev so zavarovane z drugimi oblikami pravnega varstva, in sicer kazenskopravno (npr. kazniva dejanja zoper uradno dolžnost - kršitev človeškega dostojanstva z zlorabo uradnega položaja ali uradnih pravic in izsiljevanje izjave po 270. členu Kazenskega zakonika Republike Slovenije), upravnopravno oz. delovnopravno (disciplinska kršitev) in civilnopravno (kršitev osebnostnih pravic). O tem glej Bavcon v Pavčnik et al., 1997, str. 406-439 in Polajnar-Pavčnik, ibid., str.150-172.

35 Gre t.i. teorijo dostojanstva kot eno od teorij o vlogi procesnih pravic, ki je zastopana predvsem v pravnih sistemih, ki temeljijo na občem pravu. Podrobneje v Allan, 1998, primerjaj Kanska, 2004, str. 301-302. 
Iztok Rakar

Človekovo dostojanstvo kot ustavnopravni temelj načela

zaslišanja stranke $v$ upravnem postopku

\section{Zakonska konkretizacija}

\subsection{Uvod}

Izhodišče zakonske ureditve upravnega postopka je dejstvo, da gre za konkretizacijo ustavnega prava. ${ }^{36}$ Zakonsko načelo zaslišanja stranke $v$ upravnem postopku in iz njega izvedena pravila in pravna sredstva, ki zagotavljajo njegovo uveljavitev $v$ vsakodnevni praksi odločanja upravnih organov, so torej konkretizacija ustavnih načel demokratičnosti, pravne države, enakega varstva pravic in varstva človekovega dostojanstva. Gre za pravico biti slišan, ki je eden od temeljev poštenega in nepristranskega postopka odločanja in si ga ni mogoče predstavljati brez sočasne povezanosti z načelom varstva pravic strank in z načelom materialne resnice.

Ne glede na skupna ustavnopravna izhodišča pa je treba opozoriti, da je razumevanje vsebine načela zaslišanja stranke in načela poštenega postopanja $\checkmark$ različnih sistemih upravnega prava različno.

Sistem common law temelji na nevtralnem reševanju sporov prek tretje osebe znotraj same uprave, $v$ okviru katerega so strankam priznane obsežne procesne pravice in na omejenem naknadnem sodnem nadzoru. Poštenost $v$ tem sistemu torej temelji na možnosti stranke, da je vključena $v$ quasi sodni postopek sprejema odločitve upravnega organa. $\vee$ sistemih droit administratiff upravnega prava poštenost upravnega delovanja temelji na profesionalni upravi, neštevilnih procesnih pravicah strank $v$ postopku in na striktnem nadzoru sodišč. ${ }^{37}$

$\checkmark$ francoskem upravnem pravu je pravica do zaslišanja znana pod izrazom pravica do obrambe (droits de la défense ${ }^{\beta 8}$, ki je pripoznana od primera Dame Veuve Trompier-Gravier iz leta 1944 dalje, ko je Conseil d'Etat razveljavil prefektovo odločitev na podlagi teorije splošnih pravnih načel (principes généraux du $d r o i t)$, kar je pomenilo pomemben preobrat $v$ francoskem ustavnem in upravnem

36 Za razliko od uporabe nepisanih pravil, načel in t.i. dobrih praks imajo od ustavnopravno skladne zakonske konkretizacije "korist" ne samo država in stranke v postopku, ampak tudi javnost (državljani) kot celota. $V$ moderni demokratični pravni državi zakonsko urejanje upravnega delovanja ne prispeva le $k$ večji preglednosti, pravni varnosti in predvidljivosti, ampak tudi k vsebinsko pravilni odločitvi (Broß, 2005, str. 11, P. Stelkens in Sachs v Stelkens et al., 2001, str. 40, r. št. 2a in 3, Maurer, 2004, str. 484-485, r. št. 8 in str. 486-487, r. št. 10, Jerovšek $v$ Jerovšek in Trpin, 2004, str. 86 in Kanska, 2004, str. 325).

37 Bignami, 2005, str. 15-16 in 23.

38 Pravico do obrambe kot eno od splošnih pravnih načel tvorijo pravica do zaslišanja in pravila konktradiktornosti postopka. Splošna pravna načela tvorijo naravno pravo, temeljne človekove pravice in tisto, kar je pošteno in pravično (angl. fair and just) (Crossland, 1975, str. 727). 


\section{Človek Rakar zaslišanja stranke $v$ upravnem postopku}

pravu. ${ }^{39}$ Kršitev pravice do (poštenega) zaslišanja je kršitev procesnih pravic (vice de forme / procedural ultra vires), zoper katero je mogoče uveljavljati sodno varstvo. ${ }^{\mathbf{4 0}}$

Nekje vmes se glede načela zaslišanja stranke nahaja nemški pravni sistem, čeprav ga sicer umeščajo v skupino droit administratiff. Glede pravice do zaslišanja se vsi trije sistemi sicer prekrivajo, vendar Bignami (2005, str. 24) meni, da sistem common law kljub temu nudi najširši krog pravic oziroma upravičenj. Ker med nemškim in slovenskim pravnim sistemom lahko potegnemo nekatere vzporednice, sta $\vee$ nadaljevanju oba predstavljena podrobneje, temu pa sledi še predstavitev prava EU kot okvira, znotraj katerega $\vee$ zadnjem času prihaja do pomembnih premikov na področju načela zaslišanja stranke in do medsebojnega vplivanja z nacionalnim pravom.

\subsection{Slovenski pravni sistem}

V Republiki Sloveniji je temeljni zakon, ki ureja postopanje upravnih organov pri odločanju o pravicah, obveznostih ali pravnih koristih posameznikov, pravnih oseb in drugih strank $v$ upravnih zadevah, zakon o splošnem upravnem postopku (ZUP). Poleg tega zakona delovanje upravnih organov urejata še dva sistemska zakona, in sicer zakon o državni upravi (ZDU-1) in zakon o javnih uslužbencih (ZJU), ki varujeta posameznika v razmerju do države (upravnega organa), da le-ta ne postane predmet neustavnega, nezakonitega ali neetičnega ravnanja, s čimer so zagotovljeni zakonski temelji za spoštovanje človekovega dostojanstva $\vee$ teh razmerjih. ${ }^{\mathbf{4 1}} \mathrm{Ne}$ glede na to, da varstvo človekovega dostojanstva ni izrecno omenjeno kot ustavno načelo in kot načelo ZUP, so ga upravni organi dolžni spoštovati. Ta dolžnost temelji na

$39 \mathrm{~V}$ sodnih postopkih je bila ta pravica prvič priznana v zadevi Tery z dne 20. 6. 1913, kjer je šlo za izrekanje sankcij disciplinskega sodišča. Splošna pravica do zališanja pred sprejemom posamične upravne odločitve je bila uveljavljena z 8. členom dekreta z dne 28. 11. 1983, ki predstavlja enega od korakov $v$ smeri kodifikacije francoskega upravnega postopkovnega prava, omeniti pa je treba tudi zakon z dne 12. 4. 2000 (Brown in Bell, 2003, str. 243-244, Braibant, 1992 (2002), str. 195, op. 168,196, 208 in 210, Bignami, 2005, str. 16, 20 in 21, op. 81 in Crossland, 1975, str. 727). Bignami (ibid., str. 21) na podlagi analize prakse Conseil d'Etat meni, da je pravica do zaslišanja $v$ vsakodnevni praksi delovanja francoskih upravnih organov daleč od tega, da bi bila splošno priznana.

40 Bignami, 2005, str. 16; Brown in Bell, 2003, str. 243.

41 ZDU-1 med drugim določa, da uprava opravlja svoje delo strokovno, politično nevtralno in nepristransko (3. člen), pri poslovanju s strankami pa mora zagotoviti spoštovanje njihove osebnosti in osebnega dostojanstva ter zagotoviti, da čim hitreje in čim lažje uresničujejo svoje pravice in pravne koristi (1. odst. 5. člena). ZJU temu ustrezno določa, da javni uslužbenec pri izvrševanju javnih nalog ravna častno $v$ skladu s pravili poklicne etike (10. člen). Poleg tega zanj veljajo omejitve glede sprejemanja daril (11. člen), za uradnike pa posebej velja načelo politične nevtralnosti in nepristranskosti (28. člen). 


\section{Iztok Rakar \\ Človekovo dostojanstvo kot ustavnopravni temelj načela zaslišanja stranke $v$ upravnem postopku}

spoštovanju nepisanih ustavnih načel, temeljnih človekovih pravic in svoboščin in zakonsko določenih načel delovanja. Varstvo človekovega dostojanstva je namreč izpeljano iz načela demokratičnosti, varovano kot temeljna človekova pravica (glej op. 33) in sestavni del načela usmerjenosti k uporabniku (glej 5. člen ZDU-1).

Kerševan (2001, str. 170 in 174-175) meni, da je načelo varstva človekovega dostojanstva $\vee$ ZUP $\vee$ veliki meri prezrto, saj naj bi bilo elemente le-tega mogoče najti le $v$ okviru načela varstva pravic strank in javnih koristi (7. člen ZUP) in v določbi, po kateri mora uradna oseba stranko opozoriti, ko glede na podano dejansko stanje izve ali sodi, da ima stranka $v$ postopku podlago za uveljavitev kakšne pravice. ${ }^{\mathbf{4 2}}$ Po drugi strani pa meni, da je ustavno načelo enakega varstva pravic, kot ga je $v$ svoji praksi opredelilo Ustavno sodišče Republike Slovenije, $v$ tistem delu, ki se nanaša na pravico izjaviti se (zaslišanje stranke), v ZUP konkretizirano ustrezno - in sicer prek načela zaslišanja stranke kot enega od temeljnih načel ZUP in njegove konkretizacije $v$ določbah zakona o pravici do udeležbe in pravic strank $v$ ugotovitvenem postopku.

Glede na $\vee$ tem prispevku predstavljeno povezavo med načelom varstva človekovega dostojanstva in načelom zaslišanja stranke menimo, da ustavno načelo varstva človekovega dostojanstva v ZUP je konkretizirano, vendar posredno - prek načela zaslišanja stranke (9. člen). ${ }^{\mathbf{4 3}}$ To hkrati pomeni, da je z načelom zaslišanja stranke dana nova podlaga za spoštovanje človekovega dostojanstva $\vee$ upravnem postopku (glej supra).

$\checkmark$ skladu z načelom zaslišanja stranke ima posameznik po ZUP vrsto procesnih pravic ${ }^{\mathbf{4 4}}$, ki pa jih ni dolžan izkoristiti, saj je upravni organ glede na podano dejansko stanje posameznika sicer dolžan opozoriti nanje, ne more pa ga prisiliti k njihovi uveljavitvi in s tem spremembi v dolžnosti. Bistveno namreč je, da upravni organ posamezniku omogoči njihovo uveljavitev. Bistvo načela zaslišanja stranke ni v tem, da mora biti posameznik navzoč pri posameznih dejanjih ugotovitvenega postopka, ampak v uresničevanju njegove vsebine, ki je, kot že omenjeno, širša - dati posamezniku možnost, da se udeležuje postopka ugotavljanja dejstev, pomembnih za odločitev, da se izjavi o vseh dejstvih in

42 Navedene določbe kot vodilo ravnanja upravnega organa po njegovem mnenju ne pokrivajo celovitega spoštovanja dostojanstva $v$ vseh fazah upravnega postopka, tako pri odnosu organa do stranke, izvedbi ugotovitvenega oz. dokaznega postopka, izrekanju sklepov v okviru postopka ipd.

43 Primerjalnopravna analiza švedske agencije za javni menedžment na temo načela dobre uprave vsebino 9. člena ZUP navaja kot reprezentativen primer zakonske določbe o načelu zaslišanja stranke (glej Statskontoret, 2005, str. 35).

44 Glej 7., 4. odst. 9., 138., 141., 146., 157., 158., 162., 237. in 238. člen ZUP (po Jerovšek v Jerovšek in Trpin, 2004, str. 87-88). 


\section{Iztok Rakar \\ Človekovo dostojanstvo kot ustavnopravni temelj načela zaslišanja stranke $v$ upravnem postopku}

okoliščinah, pomembnih za odločitev in izpodbija ugotovitve in navedbe organa in nasprotnih strank ter drugih udeležencev postopka. ${ }^{\mathbf{4 5}}$

Zaslišanja stranke ni treba izvesti v vseh primerih, kar pomeni, da iz tega načela ne izhajajo absolutne pravice, ampak pravice, ki jih lahko ZUP ali lex specialis omeji. Tega po ZUP npr. ni treba storiti v t.i. skrajšanem ugotovitvenem postopku, ki je izjema od pravila (posebnega ugotovitvenega postopka). ${ }^{\mathbf{4}}$ Seveda pa zaslišanje stranke $v$ teh primerih ni prepovedano, če to dopušča narava zadeve in hitrost postopka, kar jasno izhaja že iz dikcije zakona (»ni potrebno «). ${ }^{\mathbf{4 7}}$ Načelo zaslišanja stranke je torej lahko kršeno, če je bil izveden skrajšani ugotovitveni postopek, moral pa bi biti izveden posebni ugotovitveni postopek. $^{\mathbf{4 8}}$

Kršitev načela zaslišanja stranke je ZUP opredeljena kot absolutna bistvena kršitev pravil postopka in s tem kot razlog za pritožbo zoper izdani upravni akt. Organ prve stopnje lahko zaradi te kršitve na pritožbo stranke izda nadomestno odločbo, ne da bi pritožbo poslal v pritožbeni postopek organu druge stopnje. Zoper dokončno odločbo, ki je bila izdana brez zaslišanja stranke oziroma brez njene možnosti, da se izjavi o za odločbo pomembnih dejstvih, in če to lahko vpliva na odločitev, je dopusten še upravni spor ali drugo sodno varstvo. Če je postopek končan z dokončno ali pravnomočno odločbo, lahko stranka predlaga ali organ začne obnovo postopka. ${ }^{\mathbf{4 9}} \mathrm{Z}$ vidika nadaljnjega ustavno-

45 Androjna, 1992, str. 27-28 in Jerovšek v Jerovšek in Trpin, 2004, str. 86. Načelo zaslišanja stranke je treba ločiti od podajanja izjav kot dokaznega sredstva (188. člen ZUP), čeprav se $v$ praksi za izjavo stranke pogosto uporablja besedna zveza "dokazovanje z zaslišanjem stranke» (Kovač v Jerovšek in Trpin, 2004, str. 536-537, Jerovšek, ibid., str. 91 in Androjna, 1992, str. 28).

46 Ta postopek je mogoče izvesti $v$ treh skupinah primerov: če so dejstva, potrebna za odločitev, takoj dostopna; če so ta dejstva bolj ali manj jasno nakazana, hkrati pa je zadeva nujna $v$ javnem interesu ter če je zadeva manj pomembna in se stranki ugodi (Kovač $v$ Jerovšek in Trpin, 2004, str. 436-437 in 441; glej 1. odst. 144. člena ZUP). Opozoriti pa je treba, da se pri odločanju o tem, katere vrste postopek izvesti, od česar je nato odvisna tudi uveljavitev načela zaslišanja stranke, srečamo z nedoločenimi pravnimi pojmi, pri razlagi katerih ima upravni organ določeno polje lastne presoje - npr. nujnost ukrepov $v$ javnem interesu.

47 Kovač ( $v$ Jerovšek in Trpin, 2004, str. 441-442) navaja, da je (kljub tem zakonskim določbam - op I.R.) po ustaljeni sodni praksi treba tudi v zgoraj navedenih primerih, razen če gre za nujne ukrepe $v$ javnem interesu, izvesti posebni ugotovitveni postopek, saj je eden od njegovih glavnih namenov uresničiti načeli zaslišanja stranke in varstva pravic strank kot temeljni načeli upravnega postopka.

48 Kovač v Jerovšek in Trpin, 2004, str. 439 in 441-442.

49 Po Jerovšek v Jerovšek/Trpin, 2004, str. 91. Ostale kršitve človekovega dostojanstva v upravnem postopku pa so sankcionirane še npr. z ničnostjo odločbe (5. tč. 1. odst. 279. člena ZUP - izsiljevanje, prisiljenje ali pritisk). Vprašanje odprave ali razveljavitve po nadzorstveni pravici ostaja odprto (glej Kerševan, 2001, str. 177-178). Ustavno sodišče RS je v zadevi Up$17 / 95 \mathrm{z}$ dne 4. 7. 1996 kot edino ustavno skladno razlago načela zaslišanja stranke $v$ postopku oziroma obnovitvenega razloga možnosti udeležbe $v$ postopku določilo tisto, po kateri kršitve tega načela ne predstavljajo le primeri, ko stranka sploh ni bila vabljena in vključena v postopek, 
Iztok Rakar

Človekovo dostojanstvo kot ustavnopravni temelj načela

zaslišanja stranke $v$ upravnem postopku

sodnega varstva $v$ postopku z ustavno pritožbo pa se je po našem mnenju treba $\vee$ vseh teh primerih sklicevati tudi na kršitve človekove pravice do dostojanstva in do enakega varstva pravic.

\subsection{Nemški pravni sistem}

Kot je bilo že omenjeno, je nemški sistem upravnega prava na meji med sistemoma common law in droit administratif, kajti osrednja vloga človekovih pravic $\vee$ GG je privedla do oblikovanja sorazmerno širokega obsega procesnih pravic $\vee$ upravnih postopkih. ${ }^{\mathbf{5 0}}$

$\checkmark$ Zvezni republiki Nemčiji (ZRN) je bilo načelo zaslišanja stranke priznano od zveznih in deželnih upravnih organov ter varovano $v$ upravnem sodstvu že pred uveljavitvijo zveznega zakona o upravnem postopku (Verwaltungsverfahrensgesetz: $\vee w \vee f G)$, vendar je bilo $v$ posameznih vprašanjih delno sporno. Z uveljavitvijo zveznega zakona VwVfG leta 1977 in njegovim nadaljnjim normativnim razvojem $v$ smeri konkretizacije ustavnopravnih temeljev, njegova splošna veljava ni več sporna. Ustavnopravni temelji tega načela so načelo varstva človekovega dostojanstva, zahteva po poštenem postopku, ki je izvedena iz načela pravne države, načelo zakonitosti delovanja uprave in smiselna uporaba 1. odst. 103. člena GG. ${ }^{\mathbf{5 1}}$

$\mathrm{Na} z v e z n i$ ravni so pozitivnopravni odraz tega načela 28. člen $\vee w \vee f G, k i$ predstavlja eno od temeljnih načel znotraj splošnih določb t.i. neformalnega upravnega postopka, ki je pravilo, ter 66. in 73. člen za dve od posebnih vrst upravnega postopka (t.i. formalni postopek, ki je izjema in postopek sprejemanja načrtov). ${ }^{\mathbf{5 2}}$ Poudariti je treba, da se $\mathrm{VwVfG}$ ne uporablja za vsa upravna področja, kjer pa se uporablja, se uporablja zgolj subsidiarno, kar pomeni, da področna zakonodaja lahko določa ožjo ali širšo vsebino tega načela kot VwVfG, pa tudi oblika zaslišanja in vrsta in vsebina sodelovanja in vplivanja na

temveč tudi primeri, ko stranki ni bila dana možnost obravnavanja, na primer možnost komentiranja izjave priče oziroma komentiranja s strani priče navedenih dejstev in okoliščin, oziroma možnost udeležbe $v$ ugotovitvenem postopku ( $v$ tem primeru je šlo za stranko upravnega postopka $v$ najožjem pomenu, za t.i. aktivno stranko, ne le za stranskega udeleženca in za dejstva oziroma dokaze, ki bi lahko odločilno vplivali na izid postopka - primerjaj s sklepom Vrhovnega sodišča Republike Slovenije št. I Up 1244/2003 z dne 13. 11. 2003 in Trpin v Jerovšek in Trpin, 2004, str. 712).

50 Bignami, 2005, str. 15, op. 51

51 Maurer, 2004, str. 491, r. št. 29, Bonk in Kallerhoff v Stelkens et al., 2001, str. 689, r. št. 3 in str. 716, r. št. 73

52 Deželna zakonodaja večinoma dobesedno povzema $V w V f G$, pri čemer pa je treba opozoriti na specialno zakonodajo, ki lahko vsebuje drugačne določbe o zaslišanju in drugih pravic udeležbe oziroma sodelovanja (Bonk in Kallerhoff v Stelkens et al., 2001, str. 717, r. št. 76; Broß, 2005, str. 4). 


\section{Iztok Rakar \\ Človekovo dostojanstvo kot ustavnopravni temelj načela zaslišanja stranke $v$ upravnem postopku}

postopek so lahko različni. ${ }^{\mathbf{5 3}}$ Tudi specialne določbe znotraj samega $\vee w \vee f G$ (npr. 66. in 73. člen) imajo prednost pred 28. členom kot temeljnim določilom glede zaslišanja stranke. Ne glede na vse to bomo zaradi njegove temeljnosti in zaradi podobne ureditve na področju davkov in socialnega prava $\vee$ nadaljevanju obravnavali predvsem njegovo vsebino in z njim povezana vprašanja.

$\checkmark$ skladu z določbo 28. člena $\vee w \bigvee f G$ je udeležencu oziroma stranki (Beteiligte) ${ }^{\mathbf{5 4}}$ treba dati možnost, da se izjavi o dejstvih, pomembnih za odločitev, pred izdajo upravnega akta, ki posega $\vee$ njene pravice (eingreifender Verwaltungsakt). ${ }^{\mathbf{5 5}}$ Zaslišanja stranke ni potrebno izvesti, če upravni organ glede na okoliščine posameznega primera tako presodi, še posebej takrat, ko je podan eden od eksemplifikativno naštetih primerov $\vee \vee w \vee f G .{ }^{\mathbf{5 6}} \mathrm{Ne}$ glede na to pa tudi $\vee$ teh primerih zaslišanje ni prepovedano - prepoved velja samo $\vee$ primeru nujnega javnega interesa, pri čemer mora iti za posebej kvalificiran javni interes (zwingendes öffentliches Interesse). Ker gre za izjemo, jo je treba razlagati in uporabljati restriktivno. Upravni organ lahko zaslišanje opusti tudi $v$ drugih primerih, vendar morajo bili le-ti po svoji teži primerljivi z zakonsko navedenimi. ${ }^{\mathbf{5 7}}$

53 Izvorna ideja zakonodajalca je bila, da bi na ta način $v$ prihodnosti prišlo do poenotenja upravnega postopanja, saj naj bi zvezna in deželna zakonodaja upoštevala rešitve VwVfG. $O$ razlogih za zgolj delno uresničenje tega cilja glej Bonk in Schmitz v Stelkens et al., 2001, str. $210 \mathrm{sl}$.

54 Pojem udeleženca oziroma stranke postopka kot ga opredeljuje 13. člena VwVfG se kot krovni pravni pojem uporablja za vse načine in oblike udeležbe $v$ postopku in ima za upravni postopek podoben pomen kot pojem stranke (Partei) v civilnopravnih postopkih. Med udeležbo $v$ postopku in (potencialno) prizadetostjo obstaja povezava. Zato obstaja tudi notranja povezava med členi $13,28,66$ in $73 \mathrm{VwVfG}$, katere bistvo je $v$ tem, da potencialno prizadeti subjekt $v$ upravnem postopku svojega pravnega varstva ne uveljavlja šele naknadno $v$ (represivnem) sodnem postopku, ampak da svoj položaj zavaruje že s (preventivno) udeležbo $v$ postopku pred upravnim organom (Bonk in Schmitz v Stelkens et al., 2001, str. 445, r. št. 3 in str. 446, r. št. 5). Primerjaj s pojmom stranke $v$ slovenskem upravnem postopku v Mužina $v$ Jerovšek in Trpin, 2004, str. 180-187.

55 Ta določba $V w V f G$ odpira vrsto vprašanj, npr. o vsebini pojma upravni akt, pravica in stranka, o vrsti aktov, pri katerih je treba stranki dati možnost, da se izjavi, o položaju tretjih, o načinu zaslišanja ipd. Ta člen ne pokriva t.i. zaslišanja $v$ javnem interesu v postopkih npr. urejanja prostora. Poleg pravice do zaslišanja po VwVfG lahko določenim subjektom tako pravico daje tudi lex specialis - gre za ti.i. samostojno pravico udeležbe $v$ upravnem postop$k u$ (glej npr. 29. člen zveznega zakona o varstvu okolja (BNatSchG).

56 Glej 1. do 5. tč. 2. odst. 28. člena VwVfG. V t.i. formalnem postopku takih omejitev ni (glej 66. člen $V w V f G)$. Avtomatična izključitev zaslišanja, če je podan eden od zakonsko navedenih razlogov, ni dopustna. O izključitvi zaslišanja sicer ni potrebno izdati posebnega akta, mora pa biti ta odločitev $v$ upravnem aktu posebej obrazložena.

57 Po stališču upravnopravne doktrine je opustitev zaslišanja $v$ takih primerih praviloma dopustna le tedaj, če je to $v$ interesu stranke oziroma tretjih oseb (Bonk in Kallerhoff $v$ Stelkens et al., 2001, str. 706, r. št. 47-48). Tudi v teh primerih je potrebno izvesti tehtanje razlogov za in proti glede na okoliščine konkretnega primera. 
Iztok Rakar

Človekovo dostojanstvo kot ustavnopravni temelj načela zaslišanja stranke $v$ upravnem postopku

Možnosti izključitve zaslišanja kažejo, da je to procesna pravica, ki je ne glede na ustavnopravne temelje načela in ne glede na to, da gre splošno pravno načelo evropskega upravnega prava, lahko omejena. K temu je treba dodati tudi dejstvo, da je zaslišanje pod določenimi pogoji mogoče izvesti tudi po izdaji upravnega akta, pravno varstvo pa je mogoče uveljavljati le, če bi opustitev zaslišanja lahko vplivala na vsebino upravnega akta. ${ }^{\mathbf{5 8}}$ Ta odločitev zakonodajalca je $\vee \vee w \vee f G \vee$ zvezi s $\vee w G O$ nato še potencirana, kajti napake pri zaslišanju je mogoče odpraviti ne samo $v$ postopku s pravnimi sredstvi (Vorverfahren), ampak celo do konca postopka pred upravnim sodiščem. ${ }^{\mathbf{5 9}}$

Ta zakonska ureditev izhaja iz stališča, da ima zaslišanje zgolj pomožno (služečo) funkcijo in temelji predvsem na zahtevi po pospešitvi postopka. Na ta način je po stališču doktrine načelo zaslišanja stranke dejansko in pravno gledano minimizirano, čeprav naj to ne bi bil namen zakonodajalca. ${ }^{\mathbf{6 0}}$ Pravne dolžnosti organa namreč načeloma sicer ostajajo nespremenjene (gre za de iure primarno dolžnost organa), vendar so pravne posledice kršitve zaradi širokih možnosti popravkov napak, ki učinkujejo ex tunc, znatno relativizirane, kar VwVfG v tem smislu približuje lex imperfecta. ${ }^{\mathbf{6 1}}$

\section{Pravo EU 62}

Vprašanji varstva človekovega dostojanstva in načela zaslišanja stranke $v$ upravnem postopku sta aktualni tudi $v$ okviru prava Evropske Unije (EU), kajti dve izmed osrednjih vprašanj prava EU sta vprašanji učinkovitosti njegovega

58 Do odprave oziroma razveljavitve upravnega akta tako pride le $v$ primeru, če je zaradi opustitve ali napak pri zaslišanju obstajala konkretna možnost za drugačno odločitev (t.i. bistvena napaka postopka). Bistvena pa je napaka vedno takrat, ko bi lahko imela vpliv na odločitev upravnega organa, ki ga ne bi bilo mogoče več popraviti v postopku pred upravnim sodiščem (Bonk in Kallerhoff $v$ Stelkens et al., 2001, str. 712, r. št. 66 in str. 714, r. št. 69, Sachs $v$ Stelkens et al., 2001, str. 1556, r. št. 15 in str. 1558, r. št. 25; primerjaj Testen v šturm, 2002, str. 239, r. št. 2-3 in Kerševan v Jerovšek in Trpin, 2004, str. 661).

59 Wolff, 2004, str. 133, r. št. 32, Bonk in Kallerhoff v Stelkens et al., 2001, str. 717, r. št. 77 in Sachs $\vee$ Stelkens et al., 2001, str. 1578, r. št. 112. Sporno je le, ali že sama možnost ugovora (Widerspruch) predstavlja možnost odprave te napake. Zvezno upravno sodišče (BverwG) je glede tega zelo velikodušno - le-to že $v$ možnosti vložitve pravnega sredstva vidi priložnost za nadomestitev zamujenega, če izvorni upravni akt vsebuje obrazložitev in pravni pouk (glej BVerwGE 54, 276 (280); 66, 111 (114 sl.)).

60 Sachs v Stelkens et al., 2001, str. 1558, r. št. 24.

61 Sachs v Stelkens et al., 2001, str. 1557, r. št. 18 sl., podobno Maurer, 2004, str. 493, r. št. 20.

62 Zaradi poenostavitve bomo ne glede na časovni vidik uporabljali besedno zvezo Evropska unija. 


\section{Človekovo dostojanstvo Rakar zaslišanja stranke $v$ upravnem postopku}

izvrševanja in legitimnosti delovanja organov. ${ }^{\mathbf{6 3}}$ Pod pritiskom težnje za učinkovitostjo se namreč hitro lahko pojavi težnja po zmanjševanju obsega procesnih pravic, kar posameznika približuje vlogi objekta odločanja in hkrati zmanjšuje legitimnost delovanja upravnih organov. Učinkovitost in legitimnost sta dva vidika ustreznosti upravnega delovanja, med katerima obstaja stalna napetost in skupni vezni element - varstvo človekovega dostojanstva v zvezi z načelom zaslišanja stranke. ${ }^{\mathbf{6 4}}$ čeprav se pogosto poudarja učinkovitost izvrševanja prava EU, je treba ugotoviti, da učinkovito izvrševanje prava EU, ki bi temeljilo na kršitvi temeljnih človekovih pravic in splošnih pravnih načel, $v$ EU ni sprejemljivo. ${ }^{65}$

Ne glede na to, da upravni postopek na ravni EU ni urejen $v$ enotnem aktu, to ne pomeni, da ne obstaja skupek načel in pravil, ki uokvirjajo njegov potek in način izvajanja. Razvojno gledano je vsebino pravice do zaslišanja $v$ razmerju do institucij in organov EU (institucije EU) mogoče spremljati na treh ravneh, in sicer na ravni zakonodaje in drugih aktov institucij EU, prakse Sodišča Evropskih skupnosti (The Court of Justice of the European Communities: ECJ) in Pogodbe o Ustavi za Evropo (PUE). ${ }^{\mathbf{6}}$ Temeljne določbe delovanja Evropske komisije (EK) kot institucije EU, ki ustreza pojmu organa izvršilne veje oblasti, so bile namreč vsebovane že $\vee$ Rimski pogodbi in $\vee$ nizu zakonodajnih in drugih aktov iz 60-ih in 80-ih let prejšnjega stoletja. ${ }^{\mathbf{6 7}} \mathrm{K}$ širitvi vsebine in področja uporabe pravice do zaslišanja je največ pripomoglo ECJ, povzetek in ustavnopravno nadgradnjo le-tega pa sedaj predstavlja pravica do zaslišanja kot sestavni del pravice do dobrega upravljanja v PUE.

Varstvo človekovega dostojanstva in načelo zaslišanja stranke sta dve od vrednot, ki sta skupni vsem članicam EU. Načelo zaslišanja stranke je mogoče umestiti $\vee$ okvir splošnih načel evropskega prava in s tem tudi v okvir evropskega upravnega postopkovnega prava, ki jih je izoblikovalo ECJ. ${ }^{\mathbf{6}}$ Pravica do

63 Glej White Paper on Administrative Reform (učinkovitost) in Laekensko deklaracijo (legitimnost). $V$ upravnih postopkih pred institucijami EU kot stranke ne nastopajo samo države in gospodarski subjekti, ampak tudi posamezniki.

64 Glej Kanska, 2004, str. 325-326 in Bignami, 2005, str. 10, primerjaj Kerševan, 2004, str. 7-9 in Wade in Forsyth, 2004, str. 440.

65 Schwarze, 1992, str. 1371.

66 Bignami, 2005, str. 3.

67 Leta 1962 je bila za izvršitev (tedanjega) 85. in 86. člena Rimske pogodbe sprejeta Uredba $17 / 62$, v kateri je bila določena dolžnost, da je v postopkih izvrševanja konkurenčnega prava podjetjem ali njihovim združenjem treba dati možnost, da se izjavijo. Leta 1963 je EK sprejela uredbo, $v$ kateri je natančneje uredila vsebino te pravice, pri čemer se je zgledovala pri francoskem in nemškem upravnem pravu, $v 80$-ih letih pa več političnih izjav in zavezujočih pravil, s katerimi je prispevala $k$ opredelitvi pravice do poštenega zaslišanja (Bignami, 2005, str. 17 in 19).

68 Gre za načela, ki jih je ECJ izoblikovalo za sodne postopke, vendar ni razloga, da jih ne bi šteli kot zavezujoče tudi za upravne organe (enako Cassese, 2004, str. 25 in 31, op. 25). Pri 


\section{Iztok Rakar \\ Človekovo dostojanstvo kot ustavnopravni temelj načela zaslišanja stranke $v$ upravnem postopku}

zaslišanja sodi $v$ prvo skupino pravic, ki jih je ECJ izoblikovalo $v$ razmerju do institucij EU in je priznana ne glede na to, ali zakonodaja vsebuje izrecne določbe o tem. ${ }^{\mathbf{6 9}} \mathrm{V}$ zadevi Transocean Marine Paint iz leta 1974 je generalni pravobranilec Warner zastopal stališče, da je pravica biti slišan sestavni del prava EU, pri čemer se je oprl na angleško doktrino načela pravičnosti (natural justice). ECJ je sprejelo njegovo stališče z ugotovitvijo, da obstaja splošno pravilo, $v$ skladu s katerim mora biti subjektu, katerega interesi so lahko prizadeti, dana možnost, da se o tem izjavi (to make his point of view known). ${ }^{\mathbf{7 0}} \mathrm{V}$ zadevi Hoffman-La Roche iz leta 1979 je ECJ nato sprejelo stališče, da je pravica biti slišan temeljno načelo prava EU in pravica do dostopa do dokumentov, povezanih z zadevo, njen sestavni del. ${ }^{\mathbf{7 1}}$ Po tem, ko je ECJ to pravico priznalo v postopkih konkurenčnega prava, se je njena uporaba razširila še na antidumpinško pravo (zadeva Al-Jubail Fertilizer iz leta 1991), carine (zadeva France-aviation v. Commission iz leta 1994) in na druga področja, na katerih je izvršitev $v$ veliki večini primerov $v$ rokah držav članic, obseg upravičenj pa manjši kot na ostalih treh (temeljnih) področjih (podrobneje infra). Poleg tega je treba navesti, da je ne glede na področje uporabe pravica do zaslišanja omejena na primere, ko gre za posege $v$ pravice strank (adverse effect) in se ne prizna v primerih, ko gre za t.i. širšo javnost, ki bi bila prizadeta z odločitvijo (npr. različne interesne skupine). ${ }^{\mathbf{2}}$

Nadaljno stopnjo razvoja procesnih pravic predstavlja povzem standardov, ki jih je izoblikovalo ECJ, v PUE. Le-ta sicer še ni postala pozitivno pravo, vendar menimo, da je njena vsebina kljub vsemu relevantna za ta prispevek, saj predstavlja oblikovanje procesnih standardov oziroma temeljnih procesnih pravic evropskega upravnega prava na ustavnopravni ravni. Človekovo dostojanstvo, pravna država in enakopravnost so nekatere od najpomembnejših vrednot,

tem je ECJ uporabilo primerjalnopravno metodo, $v$ okviru katere se največji vpliv pripisuje nemškemu in v zadnjem času angleškemu pravu, kot širši "evropski okviru pa je treba šteti tudi akte Sveta Evrope (zlasti Evropsko konvencijo o človekovih pravicah /6. in 13. člen/ ter Resolucijo št. 31 o zaščiti posameznikov $v$ odnosu do aktov upravnih oblasti iz leta 1977 (Resolution of the Council of Europe (77) 31 of 28.9.1977 on the protection of the individual in the relation to the acts of administrative authorities)) in z njimi povezano prakso ECHR (podrobneje v Grilc in Ilešič, 2001, str. 136 sl., Hartley, 2003, str. 133 sl. in Kerševan, 2004a, str. 268; za drugačno razlago nastanka splošnih pravnih načel in temeljnih pravic glej Bignami, 2005, str. 9-14).

69 Cassese, 2004, str. 31 in 33 in Bignami, 2005, str. 14.

70 Hartley (2003, str. 155) navaja, da je ECJ s tem oblikovalo doktrino pravice do obrambe (the rights of the defence), kar je neposredni prevod francoskega koncepta pravice do obrambe (droit de la défense) in ustreza angleški doktrini pravičnosti (natural justice) in ameriškemu konceptu / načelu due process.

71 Bignami (2005, str. 3 in 20) meni, da je uveljavitev pravice do zaslišanja posledica vključitve Velike Britanije $v$ EU. Takrat naj bi namreč prišlo do rizika, da britanska sodišča ne bi hotela izvršiti aktov EK, ki so bili izdani v postopkih, nezdružljivih s temeljnimi načeli občega prava (common law), zlasti z zahtevo po poštenem in zakonitem izvrševanju oblasti. 72 Po Bignami, 2005, str. 25-42 in Hartley 2003, str. 133-156; primerjaj Ponce, 2004, str. 12, Kanska, 2004, str. 317, Nehl, 1999, str. 70-100 in Cassese, 2004, str. 31-34. 


\section{Iztok Rakar \\ Človekovo dostojanstvo kot ustavnopravni temelj načela zaslišanja stranke $v$ upravnem postopku}

navedenih $v$ preambuli Listine Unije o temeljnih pravicah (Listina) kot sestavnega dela PUE. Varstvo človekovega dostojanstva je postavljeno na prvo mesto Listine (člen II-61), načelo zaslišanja stranke pa je sestavni del pravice do dobrega upravljanja $\vee$ okviru poglavja o pravicah državljanov (II-101. člen PUE). ${ }^{\mathbf{7 3}} \mathrm{V}$ skladu s slednjo ima vsakdo pravico, da institucije, organi, uradi in agencije Unije njegove zadeve obravnavajo nepristransko, pošteno (fair) in $v$ razumnem roku. ${ }^{\mathbf{7 4}}$ Ta pravica vključuje predvsem (1) pravico vsake osebe, da se izjasni pred sprejetjem kakršnega koli posamičnega ukrepa, ki jo prizada$n e^{\mathbf{7 5}}$, (2) pravico dostopa vsake osebe do svojega spisa, ob spoštovanju legitimnih interesov zaupnosti ter poklicne in poslovne tajnosti in (3) obveznost uprave, da svoje odločitve obrazloži. Kršitev te pravice ima za posledico odškodninsko odgovornost EU (3. odst. II-101. člena PUE). Izjeme od načela zaslišanja stranke so dopustne ${ }^{\mathbf{7 6}}$, vendar doktrina meni, da vsebinsko niso konkretneje opredeljene, in to ne $v$ praksi ECJ ne $v$ teoriji (Bonk in Kallerhoff $v$ Stelkens et al., 2001, str. 716, r. št. 74).

Pomen pravice do dobrega upravljanja $\vee$ PUE je predvsem $v$ tem, da gre za horizontalno določbo, ki zmanjšuje deficit in raztresenost procesnih pravil upravnega prava za delovanje institucij in organov EU po posameznih pogodbah in

73 Pravica do dobrega upravljanja v PUE je unikum, kajti ustave članic EU je ne poznajo. Gre za t.i. upravno človekovo pravico (administrative human right), ki skupaj s pravico do učinkovitega pravnega sredstva in pravico do poštenega obravnavanja tvori pravico do upravne pravičnosti (right to administrative justice). Navezuje se na že doslej priznana splošna pravna načela, zlasti na iz načela pravne države izpeljana načela zaslišanja stranke, poštenosti postopka in enakosti orožij (P. Stelkens in Sachs v Stelkens et al., 2001, str. 102, r. št. 134d sl.). Kot teoretične temelje je treba navesti načelo zakonitosti, pojmovanje procesnih pravic kot temeljnih pravic in nove razsežnosti koncepta evropskega državljanstva, kot druge izvore pa tudi zapisano pravo EU, akte Sveta Evrope, sodno prakso ECHR, akte Evropskega varuha človekovih pravic in zakonodajo držav članic. Podrobneje v Kanska (2004).

74 Primerjaj s 1. odst. III-398. člena PUE: "Institucije, organe, urade in agencije Unije pri izvajanju njihovih nalog podpira odprta, učinkovita in neodvisna evropska uprava». Glede na to, da v EU ni jasne delitve na zakonodajne in upravne pristojnosti, se ta pravica nanaša na upravne zadeve $v$ materialnem smislu, torej ne glede na to, katera institucija jih izvaja (širša razlaga velja za 3. in 4. odst. II-101. člena PUE). PUE s to pravico nekatere elemente objektivnega načela zakonitosti transformira $v$ subjektivno pravico do dobrega upravljanja. O neprimernosti tega v okviru delovanja institucij in organov EU glej Kanska 2004, str. 299 in 326.

$75 \mathrm{Iz}$ besedila izhaja, da se pravica ne nanaša na ukrepe splošne narave, pri čemer vrsta prizadetosti ni opredeljena - nedvomno pa ne gre zgolj za ekonomsko (o tem Kanska, 2004, str. 315-317). Kdo je postopek sprožil, ni pomembno.

76 Prvi odstavek II-112. člena PUE določa, da mora biti kakršno koli omejevanje uresničevanja pravic in svoboščin, ki jih priznava Listina, predpisano z zakonom in spoštovati bistveno vsebino teh pravic in svoboščin. Ob upoštevanju načela sorazmernosti so omejitve dovoljene samo, če so potrebne in če dejansko izpolnjujejo cilje v splošnem interesu, ki jih priznava EU, ali če so potrebne zaradi zaščite pravic in svoboščin drugih. 


\section{Iztok Rakar \\ Človekovo dostojanstvo kot ustavnopravni temelj načela zaslišanja stranke $v$ upravnem postopku}

sekundarni zakonodaji. Vprašanje je, ali ta določba PUE velja tudi za posredno in kooperativno upravo. ${ }^{\text {77 }}$

Kanska (2004, str. 298-299) namreč navaja, da je bil motiv za vključitev pravice do dobrega upravljanja $v$ Listino o temeljnih pravicah Evropske unije iz leta 2000 splošna potreba po reformi neposredne evropske uprave. ${ }^{\mathbf{7 8}}$ Po njenem mnenju se zato ta pravica nanaša le na neposredno upravo, medtem ko je razširitev na kooperativno upravo vprašljiva - meni sicer, da bi to bilo v skladu z dosedanjo prakso ECJ. Kar se tiče pravice do zaslišanja kot dela pravice do dobrega upravljanja, menimo, da ta razširitev ni vprašljiva. Stališča teorije in sodna praksa ECJ namreč potrjujejo, da je treba postopke $v$ okviru kooperativne uprave ravno zaradi spoštovanja pravic strank oziroma posameznikov šteti za enotne, kajti varstvo pravic ne sme trpeti zaradi delitve postopka na več faz in med različne organe. ${ }^{79}$ Pravica do obrambe kot krovno pravno načelo, ki vključuje tudi pravico do zaslišanja, se torej $\vee$ teh postopkih uporablja, pri čemer je za čas uporabe bistveno to, kateri organ ugotavlja dejstva, na podlagi katerih pride do sprejema odločitve, ki je za stranko neugodna (adverse effect).

Kar se tiče posredne uprave ožje stališče potrjuje vsebina drugih določb II. dela PUE, kajti ne glede na II-111. člen PUE ${ }^{\mathbf{8 0}}$, je pri pravici do dobrega upravljanja izrecno navedeno, da se nanaša na neposredno upravo. To bi pomenilo, da je PUE vprašanje divergence procesnih pravil pri posrednem izvrševanju prava EU pustilo odprto in na ta način potrdilo veljavo načela procesne avtonomije držav članic. ${ }^{\mathbf{8 1}}$ Ne glede na to menimo, da bi bilo mogoče glede pravice do zaslišanja zastopati širše stališče. Pravica do zaslišanja stranke je namreč tesno povezana z varstvom človekovega dostojanstva. Ker je človekovo dostojanstvo kot eden od temeljev EU naveden $\vee$ preambuli Listine, ker njegovo spoštovanje in varstvo PUE izrecno zagotavlja v prvem členu Listine kot sestavnega dela PUE in ker le-ta ne vsebuje nobene omejitve glede organov ali vrst

77 Večino prava EU izvajajo države članice preko lastnih upravnih organov, kar se označuje z besedno zvezo "posredna uprava", manjši del pa institucije in drugi organi EU (zlasti EK) (»neposredna uprava"). Poseben primer predstavlja "kooperativna uprava" (cooperative administration oz. common administrative systems), pri kateri gre za različne oblike sodelovanja med organi držav članic in EK, in sicer skupno upravo (joint administration), decentralizirano upravo (decentralised administration) in t.i. regulatorni koncert (regulatory concert) (podrobneje $v$ Cassese, 2004).

78 Vsebina 41. člena navedenega akta je bila skoraj dobesedno povzeta $v$ Listino kot sestavni del PUE.

79 Glej primer France Aviation v. Commission in Cassese, 2004, str. 31 in 34. Procesne pravice morajo biti torej zagotovjene bodisi na ravni EU bodisi na ravni organov držav članic, ali pa na obeh ravneh, če sta med seboj povezani (glej primer Eyckeler \& Malt AG v.Commission) (proces vertikalne konvergence - Nehl, 1999, str. 80-81). O vrstah postopkov glej Cassese, 2004, str. 26-30.

80 "Določbe te listine se uporabljajo za institucije, organe, urade in agencije Unije ob spoštovanju načela subsidiarnosti, za države članice pa samo, ko izvajajo pravo Unije.॥ 
postopkov, pri katerih je človekovo dostojanstvo treba spoštovati in varovati, menimo, da bi bilo ob uporabi II-111. člena PUE mogoče zastopati tudi stališče, po katerem se pravica do zaslišanja stranke kot sestavni del pravice do dobrega upravljanja nanaša tudi na posredno upravo. ${ }^{\mathbf{8 2}}$

Taka razlaga je $v$ skladu $z$ nakazano tendenco ECJ, da skupne procesne standarde uveljavlja tudi $\vee$ postopkih posredne uprave ${ }^{\mathbf{8 3}}$, nasprotna razlaga pa podpira načelo procesne avtonomije držav članic in je povezana s prepričanjem, da imajo države članice ustrezno izoblikovane sisteme upravnega procesnega prava, zato poenotenje ni potrebno, ker bi prineslo zgolj stagnacijo razvoja evropskega upravnega prava. S slednjim je mogoče povezati stališče, da je na evropski ravni mogoče zagotoviti le najmanjšo raven procesnih pravic, kajti različni pravni sistemi lahko posameznikom nudijo več pravic $\vee$ tem ali onem pogledu, $v$ odvisnosti od njihove tradicije in vrednot. $V$ nasprotju s tem Bignami (2005, str. 96) ugotavlja, da procesne pravice, ne glede na to, da so se izoblikovale $v$ različnih zgodovinskih obdobjih in $v$ okviru različnih kulturnih tradicij ter nadnacionalnih interesov, posameznikom $v$ razmerju do institucij EU zagotavljajo več upravičenj kot v okviru izvornega kraja nastanka do tamkajšnjih oblastnih organov. $^{\mathbf{8 4}}$ To je $v$ korist subjektom, ki nastopajo nasproti organom, ki izvajajo pravo EU, kajti poteka tudi obraten proces - absorbcija evropskih načel v zakonodajo držav članic (koncept medsebojnega oplajanja cross-fertilisation) in prehajanje načel med pravnimi redi držav članic. ${ }^{\mathbf{8 5}}$ Odgovor na vprašanje, ali imajo v konkretnem upravnem postopku $v$ okviru posredne uprave načelo zaslišanja stranke in iz njega izpeljane pravice po pravu EU prednost pred nacionalno zakonodajo, pa je odvisen od presoje vsebinske (ne)skladnosti le-teh. ${ }^{\mathbf{8 6}}$

\section{Sklep}

Posamezniku kot stranki v upravnem postopku mora biti dana možnost, da se udeležuje postopka ugotavljanja dejstev, pomembnih za odločitev, da se izjavi o vseh dejstvih in okoliščinah, pomembnih za odločitev, in izpodbija

81 O razlogih za vzdrževanje načela procesne avtonomije glej Kerševan, 2004, str. 3-10.

82 Primerjaj Nehl,1999, str. 7, 80-81 in Schwarze 1992, str. 1187 sl. v Kerševan, 2004, str. 8 in Kerševan, 2004, str. 9 in 11.

83 O tem Kanska, 2004, str. 309, Kerševan, 2004a, str. 268, primerjaj Nehl, 1999, str. 80 sl.

84 Primerjaj Kerševan, 2004, str. 3 in 9 in Bignami, 2005, str. 96.

85 Bell v Kanska, 2004, str. 307, op. 64 in Cassese, 2004, str. 24, 33 in 35.

86 Več o razmerju med evropskim upravnim procesnim pravom in procesnim pravom držav članic v Kerševan, 2004 in Bonk in Schmitz v Stelkens et al., 2001, str. 190, r. št. 198 sl., str. 716 , r. št. 73 sl. in str. 1594 , r. št. 176 sl. 


\section{Iztok Rakar \\ Človekovo dostojanstvo kot ustavnopravni temelj načela zaslišanja stranke v upravnem postopku}

ugotovitve in navedbe organa in nasprotnih strank ter drugih udeležencev postopka. Na ta način se mu omogoči, da $v$ razmerju z državo nastopa kot subjekt in ne kot objekt. Ta dolžnost upravnega organa izvira iz varstva človekovega dostojanstva kot temeljnega vrednostnega izhodišča sodobnih demokratičnih državnih ureditev.

Glede na to je po našem mnenju primarni ustavnopravni temelj načela zaslišanja stranke $v$ upravnem postopku spoštovanje človekovega dostojanstva kot ene izmed osrednjih vrednot nove slovenske ustavne ureditve. Kršitev zakonsko določene vsebine in načina uresničevanja tega načela zato ne pomeni le absolutne bistvene kršitve določb zakona o splošnem upravnem postopku in kršitve človekove pravice do enakega varstva pravic, ampak tudi človekove pravice do osebnega dostojanstva.

Iztok Rakar je leta 1998 diplomiral s področja upravnega prava. Leta 1999 se je zaposlil kot sodniški pripravnik na Višjem sodišču v Ljubljani, leta 2000 pa kot asistent za upravnopravno področje na Visoki upravni šoli v Ljubljani, leto kasneje se je vpisal na podiplomski študij javne uprave na Pravni fakulteti v Ljubljani ter istega leta opravil strokovni izpit za zaposlene $v$ državni upravi, leto kasneje pa tudi pravosodni izpit (državni pravniški izpit). Leta 2004 je magistriral na Pravni fakulteti v Ljubljani in dve leti zatem postal doktorski kandidat na Pravni fakulteti Univerze $v$ Ljubljani z naslovom doktorske disertacije Vključevanje javnosti $v$ delovanje izvršilne veje oblasti pri sprejemanju splošnih pravnih aktov $v$ Republiki Sloveniji pod mentorstvom prof. dr. Rajka Pirnata in somentorstvom izr. prof. dr. Gregorja Viranta. 


\section{Iztok Rakar \\ Človekovo dostojanstvo kot ustavnopravni temelj načela zaslišanja stranke $v$ upravnem postopku}

\section{Literatura in viri}

- $\quad$ Allan, T. R. S. (1998): Procedural Fairness and the Duty of Respect, Oxford Journal of Legal Studies, let. 18, str. 497-515.

- Androjna, V. (1992): Upravni postopek in upravni spor (6., pred. in dop. izd., ponatis), Uradni list Republike Slovenije, Ljubljana.

- Bignami, F. (2005): Creating European Rights: National Values and Supranational Interests, Duke Law School Working Paper Series, Year 2005, Paper 2. http://lsr.nellco.org/cgi/viewcontent.cgi?article=1001\&context=duke/fs, 15. 5. 2006.

- Bogdanor, V. (ur.) (2003): The British Constitution in the twentieth Century, Oxford University Press, Oxford.

- Böckenförde, E.-W. (2004): Bleibt die Menschenwürde unantastbar? Angriff auf Artikel 1 GG, Blätter für deutsche und internationale Politik, št. 10/2004, http://www.wissensgesellschaft.org/themen/biopolitik/menschenwuerde.pdf. 15. 5. 2006.

- Braibant, G. (1992 (2002)): Administrativno pravo francuske (Le droit administratif français). CID, Podgorica in JP Službeni list SRJ, Beograd, prevedla Katarina Damjanović.

- Breznik, J. et al. (2004): Zakon o splošnem upravnem postopku s komentarjem (2., dopolnjena izd.), GV založba, Ljubljana.

- Broß, S. (2005): Grundzüge eines Verwaltungsverfahrensgesetzes in einem demokratischen Rechtsstaat und die Bedeutung einer Verwaltungsgerichtsbarkeit für einen hohen Standard der öffentlichen Verwaltung. »http://www.hsfindo.org/download/vortrag2indonesien.doc, 15. 5. 2006.

- Brown, L. N. in Bell, J. S. (2003): French Administrative Law (5th ed., reprinted), Clarendon Press, Oxford.

- $\quad$ Cassese, S. (2004): European Administrative Proceedings, Law and Contemporary Problems, let. 68, št. 21, str. 21-36.

- $\quad$ Craig, P. P. (2003): Administrative Law (5th ed.), Sweet\&Maxwell, London.

- Craig, P. (ur.) in Tomkins, A. (ur.) (2006): The Executive and Public Law: Power and Accountability in Comparative Perspective, Oxford University Press, Oxford.

- Crossland, H. G. (1975): Rigts of the individual to challenge administrative action before administrative courts in France and Germany, International and Comparative Law Quarterly, let. 24, oktober 1975, str. 707-747. 
Iztok Rakar

Človekovo dostojanstvo kot ustavnopravni temelj načela

zaslišanja stranke $v$ upravnem postopku

- $\quad$ Farber, D. A., Eskridge jr., W. N., Frickey, P. P. (1993): Cases and materials on constitutional law - themes for the constitution's third century, West Publishing Co., St. Paul, Minnesota.

- Grilc, P. in Ilešič, T. (2001): Pravo Evropske unije (prva knjiga), Pravna fakulteta Univerze v Ljubljani in Cankarjeva založba, Ljubljana.

- Hartley, T. C. (2003): The foundations of European Community law: an introduction to the constitutional and administrative law of the European Community (5th ed.), Oxford University Press, Oxford.

- Jarass, H. D. in Pieroth, B. (2004): Grundgesetz für die Bundesrepublik Deutschland (Kommentar) (7. Auflage), Verlag C.H. Beck, München.

- Jerovšek, T. (ur.) in Trpin, G. (ur.) (2004): Zakon o splošnem upravnem postopku s komentarjem, Nebra, Ljubljana.

- Kanska, K. (2004): Towards Administrative Human Rights in the EU. Impact of the Charter of Fundamental Rights, European Law Journal, Vol. 10, No. 3, May 2004, str. 296-326.

- Kerševan, E. (2001): Uporaba ustavnih načel v upravnem postopku, Javna uprava, let. 37, št. 2, str. 165-182.

- Kerševan, E. (2004): European administrative procedure in national administrative framework, EGPA 2004 annual conference (Four months after: Administering the New Europe), el. vir.

- Kerševan, E. (2004a): Uprava in sodni nadzor, Pravna fakulteta, Ljubljana.

- Kerševan, E. (2005): Uporaba procesnih pravic strank v upravnem postopku na drugi stopnji. Pravna praksa, št. 3, str. 8-9.

- $\quad$ Maurer, H. (2004): Allgemeines Verwaltungsrecht (15. Auflage), Verlag C.H. Beck, München.

- Nehl, H. P. (1999): Principles of Administrative Procedure in EC Law, Hart Publishing, Oxford.

- Pavčnik, M. (1994): Prispevek k razlagi temeljnih pravic, Podjetje in delo, št. 56, str. 483 sl.

- Pavčnik, M. (2001): Teorija prava: prispevek k razumevanju prava (2., pregl. in dopol. izd.), Cankarjeva založba, Ljubljana.

- Pavčnik, M. (ur). et al. (1997): Temeljne pravice, Cankarjeva založba, Ljubljana.

- Ponce, J. (2004): Participatory democracy and good administration: the role of administrative procedures.

http://www.jus.unitn.it/dsg/convegni/2004/back/papers/jponce.pdf. 26. 5. 2006. 


\section{Človekovo dostojanstvo kot ustavnopravni temelj načela} zaslišanja stranke $v$ upravnem postopku

- Schwarze, J. (1992): European administrative law, Office for Official Publications of the European Communities, Luxembourg, Sweet and Maxwell, London.

- Stelkens, P., Bonk, H. J., Sachs, M. (2001): Verwaltungsverfahrensgesetz (Kommentar) (6., neubearbeitete Auflage), Verlag C.H. Beck, München.

- Sullivan, K. M. in Gunther, G. (2004): Constitutional law (15th ed.), Foundation Press, New York, N.Y.

- $\quad$ Statskontoret (2005): Principles of Good Administration In the Member States of the European Union. http://www.statskontoret.se/upload/Publikationer/2005/200504.pdf. 25. 5. 2006.

- Šturm, L. (ur.) (2002): Komentar Ustave Republike Slovenije, Fakulteta za podiplomske državne in evropske študije, Ljubljana.

- Toporišič, J. (ur.) (2003): Slovenski pravopis (6., ponovno pregl. izd.), Založba ZRC, ZRC SAZU, Ljubljana.

- Tratar, B. (1999): Iskanje nove oblike legitimnosti upravnega delovanja v smislu razvojnosti načela pravne države, Javna uprava, let. 35, št. 1 (1999), str. 213221.

- Wolff, W. (2004): Allgemeines Verwaltungsrecht (4. Auflage), Nomos Verlagsgesellschaft, Baden-Baden.

- Zalar, B. (2001): Slovenske in evropske ustavnosodne razlage in uresničevanje načela socialne države v praksi, Dignitas, št. 19-20 (2001), str. 3-148.

PRAVNI VIRI

- $\quad$ http://zakonodaja.gov.si/

- $\quad$ http://www.us-rs.si/

- $\quad$ http://bundesrecht.juris.de/ 
Iztok Rakar

Človekovo dostojanstvo kot ustavnopravni temelj načela

zaslišanja stranke $v$ upravnem postopku

\section{SUMMARY}

\section{Human dignity as the constitutional basis of the principle of audiatur et altera pars in administrative procedures}

The aim of administrative procedures is to resolve the conflicts between individual and public interests which an administrative body has to settle by means of a decision. The decision-making process in administrative procedures is usually concluded with the issuing of a decision as a unilateral authoritative legal act issued by the administrative body as the superior entity within the framework of exercising its authority function without negotiating with the party. We are therefore dealing with a classic example of an authoritative relationship between an individual and the state which needs to be placed within the constitutional framework in modern democratic countries. This means that such a relationship is not authoritative in the sense of arbitrariness, an ignorant relationship of the state towards individuals. While it is true that the final decision is adopted by a state body independently and that it is not possible to talk about the equal status of the two parties at this stage, this is only one of the phases of the procedure, governed by law, of one of the forms of state operation. The administrative procedure as a whole needs to be organised in such a way that it ensures the respect for fundamental constitutional values which relate to the relationship between the state and the individual; one of these is unequivocally human dignity.

Although human dignity represents one of the fundamental values of legal order, its legal definition poses some problems. The concept of human dignity is namely an expression of the philosophical idea of man who, irrespective of his origins, gender, religion, ethnic origin or any other criteria, has a certain value which cannot be lost nor taken away merely on the basis of his existence. Due to difficulties relating to the positive definition of this concept, human dignity is usually defined in negative terms; that is, by means of defining its infringements. Proceeding from the above, and from the nature of authoritative decisionmaking in administrative procedures, human dignity can be defined as the prohibition of treating a person as an object in proceedings before state authorities. In particular, this can be achieved by affording individuals the opportunity to participate in the decision-making process as regards his rights, duties and legal entitlements. These include the right 
to be involved in the fact-finding procedure, to provide a statement regarding all facts and circumstances important for the adoption of a decision, and to contest the findings and allegations of the body and other parties involved in the procedure (the so-called principle of audiatur et altera pars, under which parties to a case should be entitled to be heard). In this way the individual is "transformed" from an object into the subject of the procedure which means that he is not considered to be a burden or cost.

Contrary to the predominant point of view of the Slovenian theoreticians as well as constitutional and judicial practices which consider the principle of democracy and the principle of equal protection of rights to be the main constitutional and judicial bases of the principle of audiatur et altera pars in administrative procedures, we are of the opinion that the principle of protection of human dignity should also be included as a fundamental criterion. Further, we think that the protection of human dignity is the primary constitutional basis of the principle of audiatur et altera pars in administrative procedures. This view stems from the fact that human rights and fundamental freedoms are one of the central starting points, objectives and aims for the sake of which the new Slovenian Constitution has been adopted, while one of the main aims of the protection of fundamental human rights is the protection of human dignity. Accordingly, it is our opinion that in the event of infringement of this principle in legal protection procedures reference should also be made to the infringement of the human right to dignity.

From a comparative legal point of view, the connection of the principle of audiatur et altera pars in administrative procedures to the protection of human dignity is explicitly emphasized in the German constitutional doctrine and practice. In addition, the German theory also derives the principle of audiatur et altera pars from the requirement for a fair procedure which stems from the principle of the rule of law, whereas the English theory places the principle of audiatur et altera pars within the framework of the principle of natural justice, while the American theory points to the framework of procedural due process.

This contribution also presents the legal concretisation of the principle of audiatur et altera pars in administrative procedures in the Slovenian and German legislation and EU law.

In Slovenia, the General Administrative Procedure Act is the main act which governs the conduct of administrative bodies in the process of deciding on the rights, obligations or legal entitlements of individuals, 
Iztok Rakar

Človekovo dostojanstvo kot ustavnopravni temelj načela

zaslišanja stranke $v$ upravnem postopku

legal persons and other parties in administrative matters. In addition to the above-mentioned Act, two other framework laws govern the conduct of administrative bodies, namely the State Administration Act and the Civil Servants Act which protect individuals in relation to the state (administrative bodies) so that they do not become the subject of unconstitutional, unlawful or unethical conduct, thus ensuring the legal bases for the respect for human dignity in these relations. Irrespective of the fact that the protection of human dignity is not explicitly mentioned as a constitutional principle and the principle of the General Administrative Procedure Act, civil servants are obliged to respect it. This obligation is based on the respect for unwritten constitutional principles, fundamental human rights and freedoms and legally determined principles of conduct. Protection of human dignity is namely derived from the principle of democracy, protected as a fundamental human right and part of the principle of useroriented policy. Although Slovenian theoreticians think that the principle of protection of human dignity is largely overlooked in the General Administrative Procedure Act we do not share the same opinion, given the fact that, according to the abovementioned, its protection is ensured through the principle of audiatur et altera pars. This principle is one of the fundamental principles of the General Administrative Procedure Act which is concretized by means of the provisions of the act governing the right to participation, the rights of parties in the fact-finding procedure and legal protection in the event of infringement.

Administrative bodies in the Federal Republic of Germany acknowledged the principle of audiatur et altera pars and courts even protected it prior to the enforcement of the federal act on administrative procedure (Verwatungsverfahrensgesetz: $\mathrm{VwVfG}$ ); its general validity is no longer disputable following its adoption and further development in the direction of the concretisation of constitutional bases. In spite of this the German theoreticians are of the opinion that legislative solutions reveal that the principle of audiatur et altera pars is actually and legally minimized even though this is not the intention of legislators. Legislative solutions should be derived from the viewpoint that hearings only have an auxiliary (supporting) function and that they should, in particular, be based on the requirement for the expedition of procedures.

The protection of human dignity and the principle of audiatur et altera pars in administrative procedures are two issues being considered within the framework of the European Union law because two of the central 
legal issues of EU law relate to the efficiency of its implementation and the legitimacy of the conducting bodies. Efficiency and legitimacy are two aspects of the adequacy of administrative work; there exists a constant tension between these two aspects and a joint cohesive element - the protection of human dignity with regard to the principle of audiatur et altera pars. Even though the administrative procedure at the EU level is not organised in a single act, this does not imply that there does not exist a set of principles and rules which frames both its conduct and manner of implementation. From a development perspective, the content of the right to be heard in relation to the EU institutions and bodies can be monitored at three levels: at the level of legislation and other acts of the EU institutions, at the level of the case-law at work in the Court of Justice of the European Communities, and at the level of the Treaty Establishing the Constitution for Europe. Although the Treaty Establishing the Constitution for Europe is not yet in force, it is nevertheless important because of the indicated establishment of procedural standards or fundamental procedural rights of the European administrative law at the constitutional level. The right to be heard in the Treaty Establishing the Constitution for Europe is a constituent part of good governance. The value of this condition lies in the fact that we are dealing with a horizontal provision which limits the deficit and fragmentation of the procedural rules of administrative law for the functioning of the EU institutions and bodies in individual contracts and secondary legislation. In our opinion the right to good governance relates not just to the immediate European administration but also to the indirect and co-operative administration. 